\title{
THE STATE AS A SUBJECT OF FINANCIAL LAW IN THE FACE OF PUBLIC FINANCE REFORMS IN THE $21^{\text {ST }}$ CENTURY IN EUROPE
}

Financial law regulates a special part of social relations and defines some of its subjects. It gives them legal rights or duties, which ensure to form, distribute and use the state budget. The issue of a state as a subject of law has not been precisely defined in the financial theory of law yet. According to financial law, we may distinguish the subjects of law and the subjects of law relationship.

The subject of financial law is a person or organization that has the ability to use their rights and can be a subject in a real relationship. Thus the subject of a relation means a person who can really be in a relationship. For example, at this moment in the Russian Federation we are living in the uninterrupted process when legislation is changing all the time. Therefore we must take advantage of international experience of development.

It's worth noting here that in Russia we have, first of all, the financial law which includes the budget law and tax law. In the Russian Federation the main source of budgetary law is the Budget Code, which is based on the Constitution of the Russian Federation and federal legislation ${ }^{1}$.

According to the Constitution of the Russian Federation, Russia has about 89 subjects, which also have the rights in the regional legislation. So we live in the federal state where every subject is independent and has equal rights in legislation ${ }^{2}$.

The main process of budget law development started at the end of 1991 and is still in progress ${ }^{3}$. In spite of the fact that the fundamental subject of financial law in Russia is the state, the budget legislation does not secure it. The core of the idea

Карасева М.В. Финансовое право. М., 2006. С. 89.

The Constitution of the Russian Federation of 12 December 1993, Articles 5,10, 72.

Карасева М. В. Финансовое право Российской ФедерацииМ., 2002. С. 103. 
of state development should be based on the theory of finance, legislation of the Russian Federation in the financial sphere and court practice ${ }^{4}$.

According to our legislation, the state has the legal ability to form the federal budget, to form the federal tax and to take taxes. The state of Russia is a difficult subject in financial law which includes the Russian Federation and the subjects of the Russian Federation. Every part is independent ${ }^{5}$. Our practice gives us some examples when we say about the state as the state organ and in some cases about the state in general. But everywhere the state organ is answerable for debts of the state subjects which do not have the independent power as the state and therefore they do not have enough rights in the budget law as the state ${ }^{6}$.

Politics is the activity of the state power and management organs reflecting social life and economic structure of the state, as well as interests and goals of many political organizations and parties. It is worth noting here that politics is the main condition to form other legal norms ${ }^{7}$. As practice shows, the activity of the state in the sphere of finance realizing its sovereign rights that produce negative consequences may lead to political responsibility. The construction of the state budget is a very important argument that proves that there has been a breaking point in conflict situations. That is why the budget is the basic instrument that forms political stability. The quality of state activities in the sphere of budget legislation is dependent on the frequency of voting by its people. According to theoretical knowledge, the idea of frequent changes of senior statesmen can be regarded in two ways: either their resignation is a result of their intentional violation of state organs functions, or a result of resignation, government discharge, i.e. constitutional legal responsibility, or it is a compromise of political forces to divide a part of power functions and to express their dissatisfaction with current reforms, i.e. political responsibility.

Therefore, in my opinion, political responsibility of a state is a measure of social influence on a state that is being realized in a form of people power and is determined by dissatisfaction with the reforms that results in power division and government resignation.

Political responsibility of a state in the financial sphere with sanctions in the form of mass meetings, demonstrations, strikes protesting against delays or nonpayment of salaries, transforms into legal mechanisms of state reaction to its own drawbacks. It may result in changing leaders of the executive power, correcting laws, decreasing the government's expenditures, etc.

Корельский В., Перевалов В.М. Теория государств и права. М., 1997. С. 430.

Карасева М.В. Финансовое правоотношение. М, 2001.С..88.

Малько А. Конституционное право Российской Федерации. М., 2001. С. 251.

Озеров С.И., Шведова Н.Ю. Словарь русского языка: 80000 слов. С. 553. 
The State as a Subject of Financial Law in the Face of Public Finance Reforms...

These statements are based on several principles; first of all, these relations concern mainly the interests of economic agents that are called tax payers. Second, they also concern the interests of those who receive these taxes. Summing up, these principles are based on political condition and participants of a budget process ${ }^{8}$. 


\section{Streszczenie}

Zagadnienie państwa jako przedmiotu regulacji prawa finansowego nie zostało do tej pory dosyć precyzyjnie wyjaśnione. Jak pokazuje praktyka, działalność państwa w sferze finansów, które realizuje swoje suwerenne prawa, może wywoływać negatywne konsekwencje i tym samym prowadzić do politycznej odpowiedzialności. Działalność polityczna wpływa na społeczno-ekonomiczną strukturę państwa, co jest efektem realizacji interesów i celów organizacji oraz partii politycznych. 